\title{
Borkhausenia crimnodes Meyrick, 1912 (Lepidoptera, Oecophoridae), a southern hemisphere species resident in Portugal
}

\author{
Martin F. V. Corley ${ }^{1,2}$, Sónia Ferreira ${ }^{2}$, \\ Alexander L. Lvovsky ${ }^{3}$, Jorge Rosete ${ }^{4}$ \\ 1 Corresponding author: Pucketty Farm Cottage, Faringdon, Oxfordshire SN7 8JP, U.K.; martin.corley@btinternet.com \\ 2 CIBIO-InBIO, Centro de Investigação em Biodiversidade e Recursos Genéticos, Universidade do Porto, Campus \\ Agrário de Vairão, P-4485-61 Vairão, Portugal; hiporame@gmail.com \\ 3 Zoological Institute, Russian Academy of Sciences, 1 Universitetskaya Emb., St Petersburg, Russia; Alexander. \\ Lvovsky@zin.ru \\ 4 Urbanização Lourisol, Rua Manuel Cerqueira Nobrega, Lote 16, 2. frente, P-3105-165 Louriçal, Pombal, Portugal; \\ roseteprof@gmail.com \\ http://zoobank.org/AA2BD4BF-933D-4F87-8B4B-3D04380E8DD0
}

Received 27 October 2016; accepted 17 November 2016; published: 20 January 2017

Subject Editor: Lauri Kaila.

\begin{abstract}
Borkhausenia crimnodes Meyrick, 1912, a species described from Argentina, has been found resident in Beira Litoral, Portugal, constituting its first records in Europe. Borkhausenia intumescens Meyrick, 1921, described from South Africa, is shown to be synonymous with B. crimnodes, described from Argentina. COI barcode sequencing has shown that a Portuguese specimen has $100 \%$ similarity with specimens collected in South Africa. The origin of the Portuguese population remains unclear but it is likely to be connected with timber importation for the paper industry. Male and female genitalia of B. crimnodes type and the Portuguese specimens are illustrated and described.
\end{abstract}

\section{Introduction}

Nine specimens of an oecophorid moth have been taken by Jorge Rosete on separate occasions from five different localities in central Portugal between July 2012 and July 2016. The first specimen, a female which appeared to belong to Oecophoridae, was examined in 2013 by Martin Corley. The following year, dissection of a male evidently belonging to the same species confirmed the family placement but could not be recognised as any known European member of that family. The possibility that it was an adventive from another continent was considered more likely than that it was a native of Portugal.

Central Portugal is dominated in many areas by plantations of eucalyptus. This, together with the fact that there are more Oecophoridae species in Australia than in any other continent, gave rise to the consideration that the species might have an Australian origin. Other Australian Oecophori- 
dae have arrived in Europe as adventives, such as Tachystola acroxantha (Meyrick, 1885) (Clutterbuck 1910; Agassiz 1971) and Barea asbolaea (Meyrick, 1883) (Oakes et al. 2010). Therefore, the first attempts to identify the Portuguese moths followed this avenue. At the suggestion of Martin Honey, photographs of the female genitalia and the moth were sent to E. D. Edwards at Canberra, who suggested it might be the previously unknown female of one of the undescribed species of the genus Oncomerista Common, 2000, since the female of the only described species, O. ochrophaea (Meyrick, 1883) has a signum consisting of radiating spines. In 2013, after a male had been found, it became clear that the Portuguese species did not belong to Oncomerista. Furthermore, a search of the three volumes on Australian Oecophoridae (Common 1994, 1997, 2000) did not produce any plausible candidate for the Portuguese species.

In 2016, a DNA sample was taken for barcoding. This gave a 100\% match on BOLD with three unidentified specimens that had been captured in South Africa. This new information opened up new possibilities. Images of the moth and the genitalia of both sexes were sent to Alexander Lvovsky (Russia), who has a wide knowledge of Old World Oecophoridae. He was able to determine that the Portuguese specimens belong to Borkhausenia intumescens Meyrick, 1921, described from Port Elizabeth in South Africa. At the suggestion of AL, MFVC studied the type of the Argentinian B. crimnodes Meyrick, 1912 at BMNH. From this it became evident that Borkhausenia intumescens is a junior synonym of $B$. crimnodes.

\section{Material and methods}

Nine specimens of B. crimnodes have so far been captured in Beira Litoral, Portugal by JR (Table 1, Fig. 1), specimens were always seen singly. In addition, the following museum material has been examined:

Borkhausenia crimnodes Meyrick, 1912. Holotype: Argentina: Parana. R. `o6 [1906] J.F.G. Clarke male gen. prep. 4765. (BMNH), seen by MFVC.

Borkhausenia intumescens Meyrick, 1921. Two specimens. Lectotype in DNMNH, seen by AL, labelled 'Borkhausenia intumescens M. Type No. 774' 'Port Elizabeth, Fitz Simons 25.12.16, Coll. Janse' '24 81' 'G 8241'. Second specimen in BMNH, South Africa: Cape Province, Port Elizabeth, probably a paratype, but not labelled as such, seen by MFVC.

Table 1. Borkhausenia crimnodes specimens captured in Portugal. For each we list the Municipality, locality, the UTM coordinates, date of collection, genitalia preparation code when applicable and collection where the specimens are deposited.

\begin{tabular}{|c|c|c|c|c|c|}
\hline Municipality & Locality & UTM & Date & Gen. prep. & Collection \\
\hline Pombal & Louriçal & 29TNE2228 & 27.vii.2012 & § Corley gen. prep. 4109 & J. Rosete \\
\hline Pombal & Louriçal & 29TNE2228 & 18.x.2013 & & M. Corley \\
\hline Pombal & Louriçal & 29TNE2228 & 14.ix.2014 & & J. Rosete \\
\hline Pombal & Louriçal & 29TNE2228 & 21.ix.2014 & & J. Rosete \\
\hline Pombal & Louriçal & 29TNE2228 & 8.vii.2016 & & J. Rosete \\
\hline Pombal & Louriçal: Casais do Porto & 29TNE2329 & 11.vi.2015 & & J. Rosete \\
\hline Pombal & $\begin{array}{l}\text { Carriço: Mata do Urso, } \\
\text { Lagoa de São José }\end{array}$ & 29TNE1128 & 17.viii. 2012 & & J. Rosete \\
\hline Ansião & $2 \mathrm{~km}$ east of Ansião & 29TNE5019 & 13.iv.2014 & $\$$ Corley gen. prep. 4172 & J. Rosete \\
\hline Soure & Paúl da Madriz & 29TNE3142 & 15.vii.2016 & & J. Rosete \\
\hline
\end{tabular}




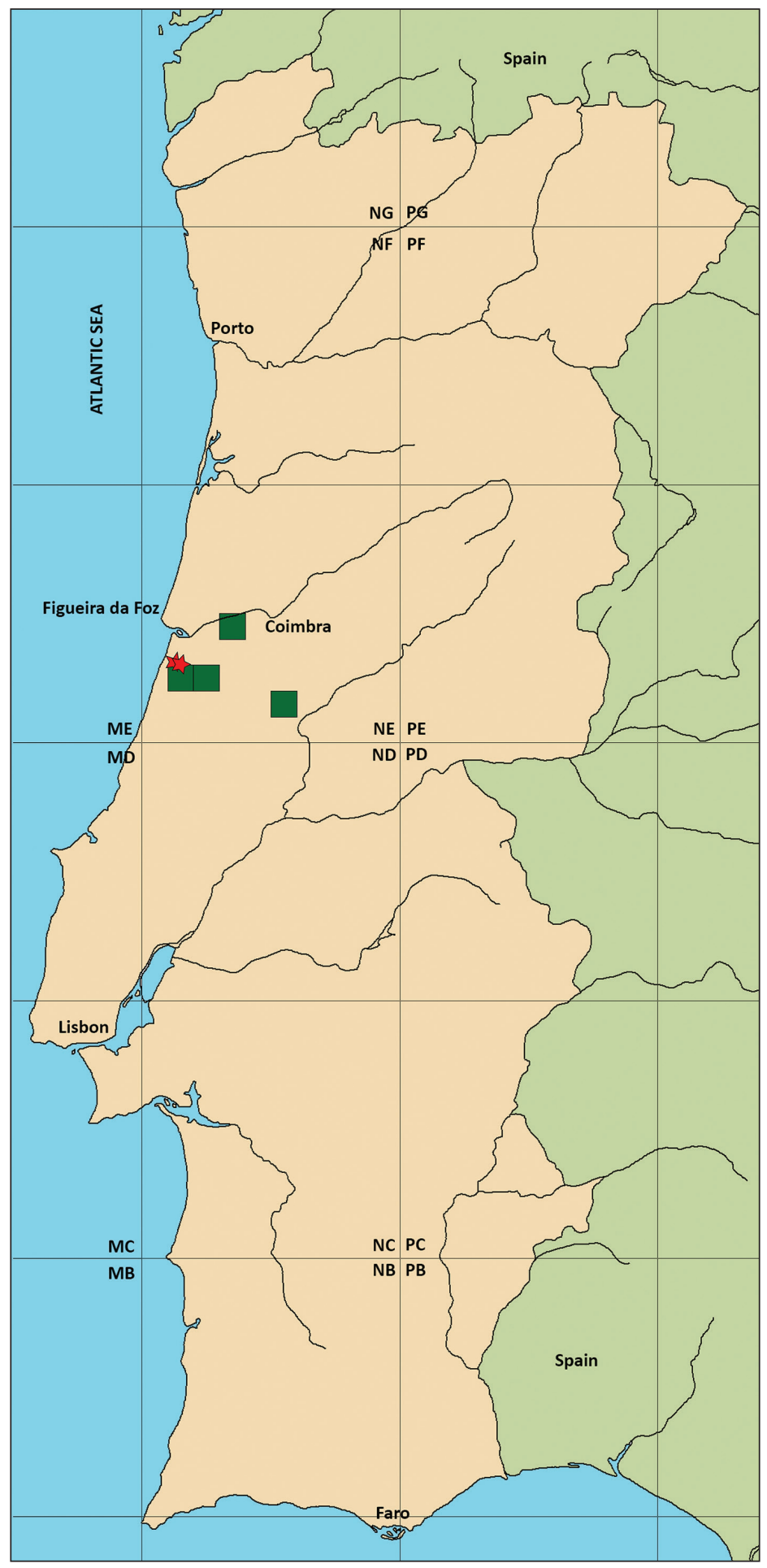

Figure 1. Distribution of $B$. crimnodes in Portugal (green squares). Red stars indicate the location of paper mills. 


\section{DNA extraction and sequencing}

Genomic DNA was extracted from leg tissue (Table 1) using EasySpin Genomic DNA Tissue Kit (Citomed) following manufacturer's protocol. The cytochrome c oxidase I (COI) barcoding fragment was amplified as two overlapping fragments, using two sets of primers. For the first fragment, primers LepF (Hebert et al. 2004) and MlepR (Hajibabaei et al., 2006) were used, while primers LepR (Hebert et al. 2004) and MlepF (Hajibabaei et al. 2006) were used to amplify the second fragment.

Both PCR reactions had $10 \mu \mathrm{L}$ of final volume, containing $5 \mu \mathrm{L}$ of Multiplex PCR Master Mix (QIAGEN), $0.4 \mu \mathrm{M}$ of each primer, and $1-2 \mu \mathrm{L}$ of DNA. PCR amplification was carried out on a T100 Thermal Cycler (BioRad) using the following conditions: initial denaturation at $95{ }^{\circ} \mathrm{C}$ for $15 \mathrm{~min} ; 5$ cycles at $95{ }^{\circ} \mathrm{C}$ for $30 \mathrm{~s}, 47^{\circ} \mathrm{C}$ for $45 \mathrm{~s}, 72{ }^{\circ} \mathrm{C}$ for $45 \mathrm{~s}$; then 40 cycles at $95{ }^{\circ} \mathrm{C}$ for $30 \mathrm{~s}, 51^{\circ} \mathrm{C}$ for $45 \mathrm{~s}$, $72{ }^{\circ} \mathrm{C}$ for $45 \mathrm{~s}$; and a final elongation step at $60{ }^{\circ} \mathrm{C}$ for $10 \mathrm{~min}$. The barcodes were sequenced in an Illumina Miseq platform, following the approach described by Shokralla et al. (2015).

We used OBITools (https://git.metabarcoding.org/obitools/obitools) for general sequence processing. Geneious v.6.1.5 (http://www.geneious.com/) was used for final sequence assembly. The sequence obtained was blasted against GenBank and BOLD databases. The average divergence (uncorrected p-distance) between the sequence of Portuguese specimen and Borkhausenia sp. COI sequences available in GenBank and BOLD was calculated in MEGA v.5.2.1 (Tamura et al. 2011).

\section{Abbreviations}

BMNH Natural History Museum, London

DNMNH Ditsong National Museum of Natural History, Pretoria, formerly Transvaal Museum.

\section{Results}

Borkhausenia crimnodes Meyrick, 1912, Trans. ent. Soc. Lond. 1911: 695.

Figs 2-3

Type locality. Argentina, Paraná.

Borkhausenia intumescens Meyrick, 1921, Ann. Transvaal Mus. 8: 99. syn. nov.

Figs 4-6

Type locality. South Africa, Port Elizabeth. Justification for the synonymy is elaborated in the section Synonymy below.

Redescription. Meyrick $(1912,1921)$ described B. crimnodes and B. intumescens separately. The redescription below is based on Portuguese specimens, but is equally applicable to the two Meyrick types. Male and female genitalia have not been described or documented previously (Figs 2-3, 6-10).

Habitus. Male and female similar (Figs 11-12). Wing length 4.4-6.0 mm; wingspan 9-13 mm. Head cream-coloured. Antenna buff, with light brown bands, scape with a pecten-like row of elongated scales. Ocellus absent. Proboscis present. Labial palp upcurved, creamy white, segment 3 


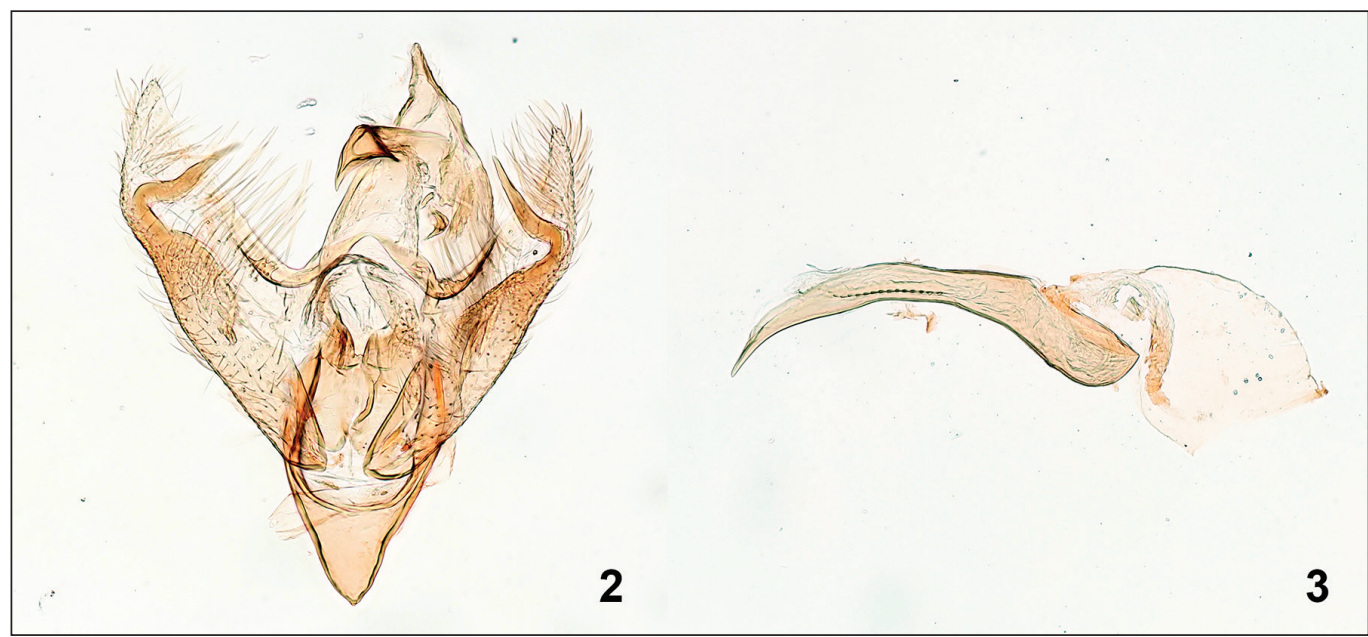

Figures 2-3. Male genitalia of Borkhausenia crimnodes Meyrick, 1912, Argentina, Paraná (BMNH). 2. Genitalia without phallus; 3. Phallus.

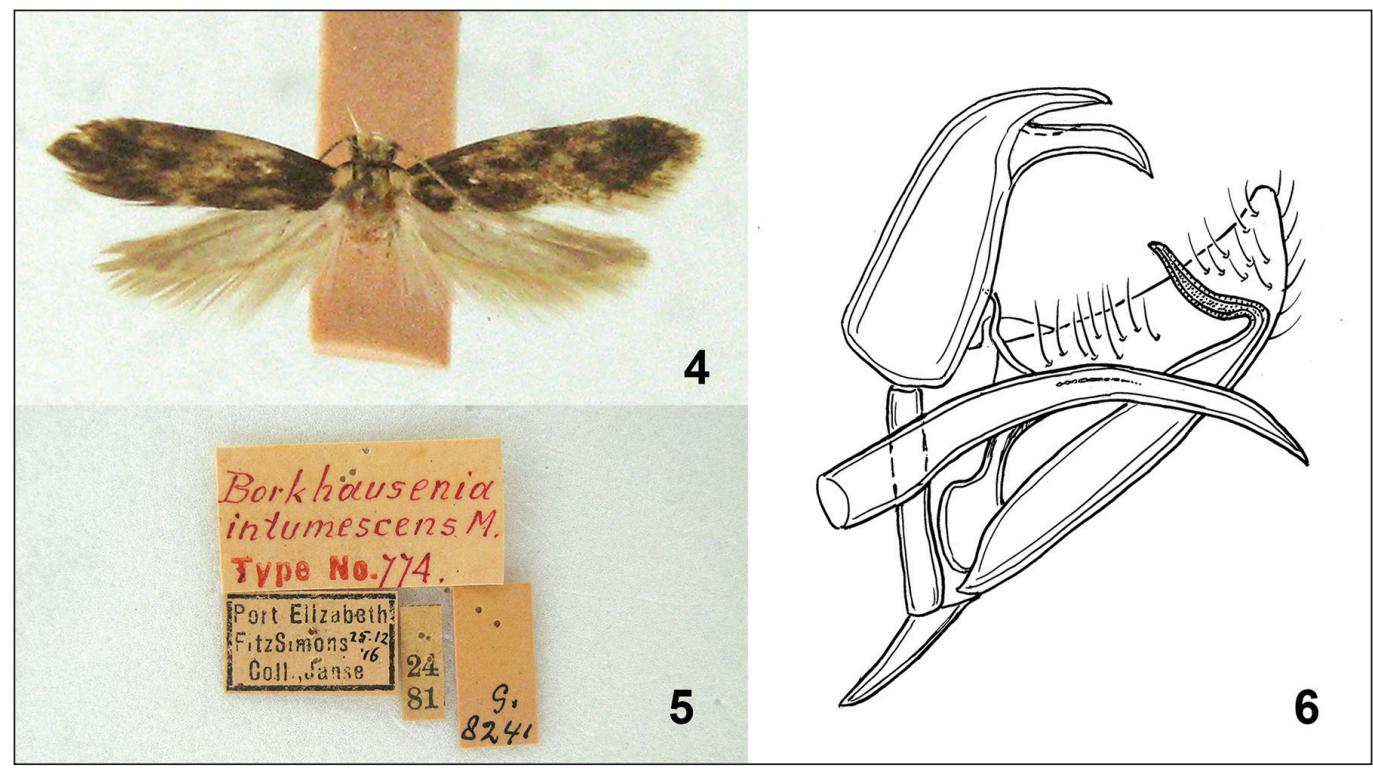

Figures 4-6. Borkhausenia intumescens Meyrick, 1921, South Africa, Port Elizabeth. 4. Lectotype male (DNMNH); 5. Labels of lectotype; 6. Male genitalia of lectotype (left valva omitted), A. Lvovsky del.

shorter than segment 2, with fuscous base and apex. Thorax creamy ochreous. Forewing elongate, narrow, creamy ochreous with extensive fuscous patches, sometimes mixed creamy ochreous, one patch at base extending to one-third on costa, and to three-fifths on dorsum with irregular outer margin, one in terminal quarter of wing and a small elongate patch along costa at middle; usually three dark fuscous round spots in mid-line, the first and third usually touching the basal and terminal dark patches respectively, the middle spot nearer the costa than the other two, a slightly 


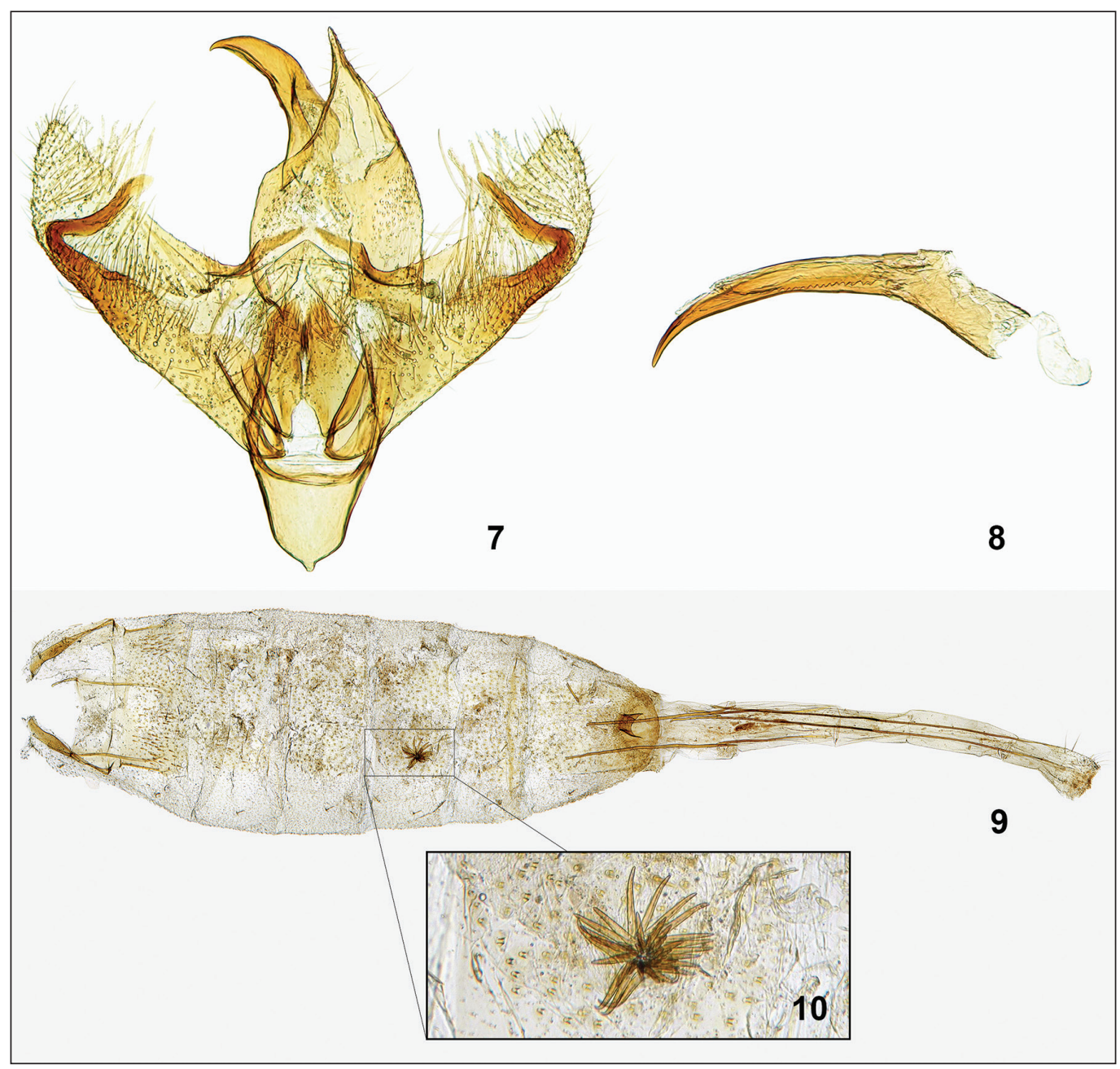

Figures 7-10. Genitalia of Portuguese specimens. 7. Male genitalia, without phallus (Portugal, Ansião); 8. Phallus (extreme base missing); 9. Female genitalia (Portugal, Louriçal); 10. Signum enlarged.

elongated plical spot is sometimes visible within basal fuscous patch; cilia creamy ochreous. Hindwings light grey. Abdomen ochreous buff.

Venation. Forewing with R4 and R5 stalked; R5 to costa near apex; Cu1 and Cu2 separately from the cell. Hindwing with Rs and M1 separately from the cell; M3 and Cu1 from one point; $\mathrm{Cu} 1$ and $\mathrm{Cu} 2$ separately from the cell.

Male genitalia (Figs 2-3, 6-8). Uncus narrowed to pointed apex. Gnathos sclerotised, narrowed to pointed apex, extending beyond uncus. Valva with narrow processes at the base of costa forming hemitranstillae; sclerotised process at the distal end of sacculus strongly elbowed at base, with a slight outwards curve in middle, distal part crossing costa of valva perpendicularly. Juxta lobes broad, slightly tapering to hairy apex. Saccus triangular to trapeziform. Phallus slightly curved, cornutus saw-like, two-fifths length of phallus. 


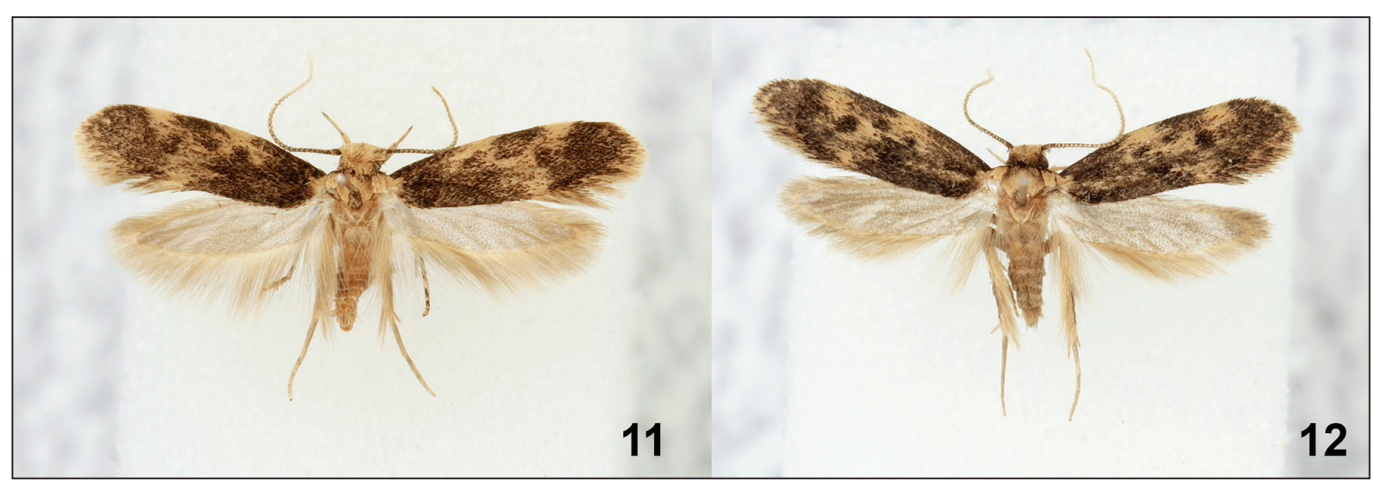

Figures 11-12. Male Portuguese specimens: 11. Louriçal, Pombal, Coimbra; 12. Paúl de Madriz, Soure, Coimbra.

Female genitalia (Figs 9-10). Ovipositor long and narrow. Small antrum sclerotised. Ductus bursae short. Signum flower-like with sclerotised narrow petals.

Variation (Figs 11-12). Some Portuguese specimens have the forewing ground colour more golden ochreous than whitish ochreous. The precise shape of the basal and apical fuscous patches is somewhat variable; the middle dark fuscous spot may be weakly developed.

\section{Synonymy}

The male genitalia illustrated in this paper (Figs 2-3, 6-8) appear to show small differences, particularly in the shape of the saccus, and possibly in the cornutus. Other differences between the dissected genitalia of the Portuguese specimens and the type of B. crimnodes are artefacts due to differences in the way the genitalia are presented in the preparation. This affects the shape of the valva and the gnathos, mainly because the cover slip of the Clarke preparation of the Argentinian type is less pressed down. The preparation of the type of $B$. intumescens was seen by AL a number of years ago and a drawing of part of it made at the time, which is reproduced here (Fig. 6). It does not show the whole of the saccus and the juxta is obscured by the phallus.

In spite of these differences there are very good reasons for considering the Portuguese specimens and the types of $B$. intumescens and $B$. crimnodes to belong to a single species. The moths are of similar size and have the same habitus (Figs 4, 11, 12). In the male genitalia, the shape of the process at the end of the sacculus, which is very distinct from other species, is similar in the specimens analysed (Figs 2, 6, 7). Differences in the cornutus are explained by the position in which this lies within the phallus; in the Portuguese specimen (Fig. 8) it appears in lateral view where it resembles a saw, while in the other two figures ( 3 and 6) it is seen edge on and only the points of the teeth are clearly evident. The saccus is clearly broader in the Portuguese preparation than in that of B. crimnodes type, but not too much significance can be placed on this character, which sometimes shows some variation in other gelechioid moths. Finally, the Portuguese moth barcoded is $100 \%$ identical to three specimens (details below under Molecular analysis) from South Africa which are illustrated in BOLD and have the same habitus as the Portuguese specimens, $B$. intumescens and $B$. crimnodes. We are fully convinced that $B$. intumescens, $B$. crimnodes, and the Portuguese specimens belong to a single species, $B$. crimnodes, of which $B$. intumescens is a junior synonym. 
Table 2. Mean (below diagonal) and standard deviation (above diagonal) sequence divergence (uncorrected p-distances) of $658 \mathrm{bp}$ fragment of cytochrome c oxidase I (COI) among pairs of species of Borkhausenia with sequences available on BOLD and GenBank.

\begin{tabular}{l|c|c|c|c|c}
\hline & B. crimnodes & B. catochopis & B. fuscescens & B. luridicomella & B. minutella \\
\hline B. crimnodes & & $1.3 \%$ & $1.3 \%$ & $1.3 \%$ & $1.2 \%$ \\
\hline B. catochopis & $13.8 \%$ & & $1.4 \%$ & $1.3 \%$ & $1.3 \%$ \\
\hline B. fuscescens & $13.2 \%$ & $15.4 \%$ & & $1.3 \%$ & $1.1 \%$ \\
\hline B. luridicomella & $13.0 \%$ & $14.1 \%$ & $13.0 \%$ & & $1.2 \%$ \\
\hline B. minutella & $12.2 \%$ & $13.1 \%$ & $10.9 \%$ & $12.2 \%$ & \\
\hline
\end{tabular}

\section{Bionomics}

The larval food of $B$. crimnodes is unknown, but is likely to be some sort of dry plant matter or debris, perhaps affected by mould or other fungi. Three specimens were taken from inside the building where JR lives, adjacent to garages. The prevalence of the species in this building is unexplained. One was taken beneath a street light, one from a porch light and three were taken at 160 watt blended mercury vapour light. Individuals have been captured in April, June, July, August, September and October, suggesting that the species is multivoltine in Portugal.

\section{Molecular analysis}

The BLAST search in BOLD (Ratnasingham and Hebert 2007) with the 658 bp COI sequence obtained from a Portuguese specimen (Specimen code - INV03258; GenBank Accession number KY053459) yielded 3 records with 100\% similarity score. The three corresponding specimens, coded as CCDB-22957-E10, CCDB-22957-E11 and CCDB-22957-F10, are deposited at the National Museum of Natural History, Smithsonian Institution and were collected in Eastern Cape - South Africa. None of the specimens has identification at family level or below. No other Borkhausenia species has been listed in 99 first results from the search in the COI Full Database despite the existence of 25 published records. Borkhausenia species pairs exhibited high levels of genetic divergence in the COI dataset analysed (uncorrected p-distance ranges 10.9-15.4) (Table 2).

\section{Discussion}

At the time of the description of Borkhausenia crimnodes, before the use of genitalia characters as a taxonomic tool had become routine practise, many genera of Microlepidoptera were understood in a much wider sense than is now the case. Borkhausenia is an example of a genus that once included large numbers of species. More than 268 species were described as Borkhausenia species (Bisby et al. 2011), but the majority are now considered to belong in other genera, sometimes even in other families. In Common $(1994,1997,2000)$ all of the approximately 40 Borkhausenia species described from Australia were placed in other genera. Due to lack of revisionary work elsewhere it is not currently possible to be sure how many species remain in the genus. The morphological and genetic distinctness of $B$. crimnodes raises the question of whether it should still be placed in Borkhausenia. Comparison of male and female genitalia with those of other European Borkhausenia species [B. fuscescens (Haworth, 1828), B. minutella (Linnaeus, 1758) (type species), B. luridicomella (Herrich-Schäffer, 1856), B. nefrax Hodges, 1974] has been made. The following 
characters are shared by $B$. crimnodes and the European species: gnathos longer than uncus, transtilla interrupted in the middle, sacculus ending in a process that partially crosses the valva, a single cornutus in the phallus (male), and the long telescopic ovipositor (female). One distinct feature of $B$. crimnodes that is not shared by the European species is the presence of a signum, which is furthermore of a form that is unusual in the family. Likewise, the cornutus is quite different from the cornuti in the European Borkhausenia species. The male genitalia characters (gnathos longer than uncus, divided transtilla and distal process of sacculus crossing the valva) do not of themselves indicate close relationship between these species, particularly as the last two characters can be found in other families of Gelechioidea.

Querying of the BOLD database for Borkhausenia species indicates that the few species which have barcode available on BOLD and GenBank $(n=5)$ are not closely related to one another, exhibiting more than $10 \%$ divergence between analysed species. Possibly the genus Borkhausenia, from which many species have already been removed, is still polyphyletic and its taxonomy certainly requires further research. In the absence of a world revision of this and related genera, we retain $B$. crimnodes in Borkhausenia.

B. crimnodes was described from Paraná in the province of Entre Rios, Argentina. Paraná is by the Paraná River, about 250 kilometres inland from Buenos Aires. B. intumescens was described from Port Elizabeth, Eastern Cape, South Africa. It is also present inland in the mountains. Those Borkhausenia species with known larvae feed on plant detritus, so this is likely to be the case also with $B$. crimnodes. Species with this larval behaviour are readily transported by human trade across considerable distances and resulting adults can readily find suitable food sources for oviposition. Examples include several species of Blastobasis originally from Madeira and now well established in the British Isles (Agassiz 1996) and B. decolorella (Wollaston, 1858) in continental Portugal (Corley 2015).

Since B. crimnodes is so far recorded from nowhere else in Europe, it would appear to have been accidentally introduced into Portugal, perhaps from South Africa or Argentina, although the possibility that it might be established elsewhere in the world cannot be ruled out. With species that are readily transported long distances by human agency, it can be difficult to establish the true country of origin. While it is puzzling that the known Portuguese sites are in Beira Litoral, remote from the main ports or airports of Lisboa and Porto, there is a smaller port at Figueira da Foz that might have provided a means of entry for Borkhausenia crimnodes. It is known that two paper mills in the region import timber from South America through Figueira da Foz port.

\section{Acknowledgements}

We are most grateful to all those who have helped towards solving the identity of $B$. crimnodes. David Lees in particular, but also Klaus Sattler and Martin Honey at BMNH gave valuable assistance, Ted Edwards made useful suggestions regarding Australian Oecophoridae, Brian Goodey did an excellent job of photographing MFVC's genitalia preparations, Ernestino Maravalhas prepared the map, Joana Veríssimo processed the specimens for barcoding. This project has received funding from the European Union's Horizon 2020 research and innovation program under grant agreement no. 668981. SF is supported by Fundação para a Ciência e Tecnologia through project grant ExpandTree (FCT-ANR/BIA-BIC/0010/2013) co-funded by the European Program COMPETE: FCOMP-01-0124-FEDER-019772 and ALL is supported by Russian state research project no. 01201351189 and the Russian Foundation for Basic Research, grant no. 14-04-00770. 


\section{References}

Agassiz D (1971) Two rediscoveries made in 1970. The Entomologist's Record and Journal of Variation 83: $39-40$.

Agassiz DJL (1996) Invasions of Lepidoptera into the British Isles. In: Emmet AM (Ed.) The moths and butterflies of Great Britain and Ireland 3. Harley Books, Colchester, 452 pp.

Bisby FA, Roskov YR, Orrell TM, Nicolson D, Paglinawan LE, Bailly N, Kirk PM, Bourgoin T, Baillargeon G, Ouvrard D (2011) Species 2000 \& ITIS Catalogue of Life: 2011 Annual Checklist. Species 2000: Reading. Clutterbuck CG (1910) Ocystola aethopis Meyrick in Devonshire. Entomologist 43: 96-97.

Common IFB (1994) Monographs on Australian Lepidoptera 3. Oecophorine Genera of Australia I. The Wingia group (Lepidoptera: Oecophoridae), 390 pp.

Common IFB (1997) Monographs on Australian Lepidoptera 5. Oecophorine Genera of Australia II. The Chezala, Philobota and Eulechria groups (Lepidoptera: Oecophoridae), $407 \mathrm{pp}$.

Common IFB (2000) Monographs on Australian Lepidoptera 8. Oecophorine Genera of Australia III. The Barea group and unplaced genera (Lepidoptera: Oecophoridae), $453 \mathrm{pp}$.

Corley MFV (2015) Lepidoptera of Continental Portugal: A fully revised list. Martin Corley, Faringdon, 288 pp.

Hajibabaei M, Janzen DH, Burns JM, Hallwachs W, Hebert PDN (2006) DNA barcodes distinguish species of tropical Lepidoptera. Proceedings of the National Academy of Sciences of the United States of America 103: 968-971. https://doi.org/10.1073/pnas.0510466103

Hebert PDN, Penton EH, Burns JM, Janzen DH, Hallwachs W (2004) Ten species in one: DNA barcoding reveals cryptic species in the neotropical skipper butterfly Astraptes fulgerator. Proceedings of the National Academy of Sciences of the United States of America 101: 14812-14817. https://doi.org/10.1073/ pnas.0406166101

Meyrick E (1912) Descriptions of South American Micro-Lepidoptera. Transactions of the Entomological Society of London 1911: 673-718. https://doi.org/10.1111/j.1365-2311.1912.tb02203.x [Published 10 February 1912]

Meyrick E (1921) Descriptions of South African Micro-Lepidoptera. Annals of the Transvaal Museum 8: 49-148.

Oakes L, Oakes H, Clifton J, Plant CW (2010) Barea asbolaea (Meyrick, 1833 [sic]) (Lep.: Oecophoridae sensu stricto): an adventive moth new to the British fauna. The Entomologist's Record and Journal of Variation 122: 185-190.

Ratnasingham S, Hebert PDN (2007) BOLD: The Barcode of Life Data System (http:/www.barcodinglife. org). Molecular Ecology Notes 7: 355-364. https://doi.org/10.1111/j.1471-8286.2007.01678.x

Shokralla S, Porter TM, Gibson JF, Dobosz R, Janzen DH, Hallwachs W, Golding GB, Hajibabaei M (2015) Massively parallel multiplex DNA sequencing for specimen identification using an Illumina MiSeq platform. Scientific Reports 5: 9687. https://doi.org/10.1038/srep09687 pmid:25884109

Tamura K, Peterson D, Peterson N, Stecher G, Nei M, Kumar S (2011) MEGA5: Molecular Evolutionary Genetics Analysis using Maximum Likelihood, Evolutionary Distance, and Maximum Parsimony Methods. Molecular Biology and Evolution 28(10): 2731-2739. https://doi.org/10.1093/molbev/msr121 